\title{
The biogeochemical fate of organic decontamination agents in low level radioactive waste disposal
}

\author{
NATALIE BYRD ${ }^{* 1}$, JONATHAN LlOYD ${ }^{1}$, JOE SMALL ${ }^{2}$,
} FRANK TAYLOR ${ }^{3}$, HEATH BAGSHAW ${ }^{4}$, CHRISTOPHER BOOTHMAN $^{1}$, KATHERINE MORRIS ${ }^{1}$

${ }^{1}$ Department of Earth and Environmental Sciences, The University of Manchester, Manchester M13 9PL, UK

(*correspondance: natalie.byrd@manchester.ac.uk)

${ }^{2}$ National Nuclear Laboratory, Chadwick House, Birchwood, Warrington WA3 6AE, UK

${ }^{3}$ Low Level Waste Repository Ltd, Pelham House, Seascale, Cumbria CA20 1DB

${ }^{4}$ School of Engineering, The Univeristy of Liverpool, Liverpool, L69 3GQ

Organic complexants in radioactive waste may challenge disposal as they can enhance subsurface mobility of contaminants via chelation. The principal sources of organic complexing agents in the UK's low level radioactive waste (LLW) inventory originate from chemical decontamination activities. Polycarboxylic organic decontaminants (e.g. citric and oxalic acid) are of interest as models underpinning Environmental Safety Cases (ESC) rely on assumptions about their biodegradability at high $\mathrm{pH}$. Experimental results will further underpin current model outputs. This work explores the biogeochemical fate of citric acid, a model decontaminant, under high $\mathrm{pH}$ conditions relevant to cementitious LLW repositories.

Anaerobic microcosm experiments were set up using a high $\mathrm{pH}$ adapted microbial inoculum. A series of microcosms

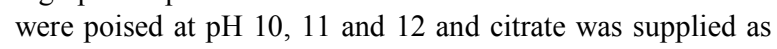
the sole electron donor and carbon source, under fermentative, $\mathrm{NO}_{3}^{-}-$, $\mathrm{Fe}(\mathrm{III})$ - and $\mathrm{SO}_{4}{ }^{2-}$ - reducing conditions. Results show citrate is oxidised using $\mathrm{NO}_{3}{ }^{-}$or $\mathrm{Fe}(\mathrm{III})$ as the electron acceptor at $\mathrm{pH}>11$. $\mathrm{Fe}(\mathrm{II})$ ingrowth was observed at $\mathrm{pH}$ values recorded up to 11.7. Mineralogical analysis of the resultant Fe-phase indicated that nanocrystalline magnetite was formed as an end product of $\mathrm{Fe}(\mathrm{III})$-reduction at high $\mathrm{pH}$. Sulfate reduction occurred in a single microcosm at $\mathrm{pH} \mathrm{10}$; here citrate was fully removed from solution.

These results will improve long-term environmental safety case development of cementitious LLW repositories. 